\title{
STUDIES
}

Vol. 14, no 2

April 2015

Unless otherwise indicated, the contents of

Peake STUDIES are (C) G. Peter Winnington 2015.

Artwork by Mervyn Peake (C) the Mervyn Peake Estate.

Acknowledgement is made to the Mervyn Peake Estate for permission to reproduce Mervyn Peake's words and images.

Edited and published by

G. Peter Winnington, 2 ch. du Collège,

1453 Mauborget, Switzerland.

Tel. +41244362232

E-mail peakestudies@gmail.com

Home page http://peakestudies.com 


\section{Dark and Deathless Rabble of Long Shadows: Peake, Dickens, Tolkien, and 'this dark hive called London'}

\section{Hadas Elber-Aviram}

Reader, forgive in me the pedant. Here you will find no fresh approach to the art of writing[,] no technical frontiers have been extended between these covers. Of this I am neither proud nor penitent.

In this my first novel I lean heavily and gladly upon an archaic manner that I love. If I am stilted I hope it will follow that I am off the ground for only thus might I have seen them face to face.

Mine only then, the fancy. Yet even here [I] am surely the debtor to many sources[:] not least among them, being, I imagine[,] the genius of Charles Dickens with his dark and deathless rabble ${ }^{1}$ of long shadows. ${ }^{2}$

THIS EVOCATIVE ADDRESS to the reader, on the third page of Peake's working notebook for chapters 60 and 6I of Titus Groan (TG), is preceded by a number of false starts, and like them has been heavily crossed out with a black crayon. As far as I know, it is Peake's only express acknowledgment of his debt to Dickens. ${ }^{3}$

That Peake was deeply influenced by Dickens will come as no surprise to students of his life and work. Peake's biographers and scholars alike have pointed out Dickensian resonances in TG and Gormenghast $(G)$, stressing especially the impact of Dickens's Bleak House $(B H)$ for the obvious reason that it was one of his favourite books and the only Dickens novel that he was commissioned to illustrate (circa 1945). ${ }^{4}$

Maeve Gilmore recounted that she read 'Bleak House, several other [novels by] Dickens' to Peake as he sat drawing illustrations (p.72). Peake's close friend Gordon Smith similarly recalled that 'when Mervyn 
illustrated a book, he first soaked himself in the text, until he felt almost a part of it. This was particularly true of Dickens and the drawings he did for Bleak House. Each book he read was an education, and Dickens was revelation' (p.100). Peter Winnington has identified a range of affinities between Peake and Dickens: similarities in anaphoric rhythm between the roofscape scene in $T G$ and the opening of $B H ;^{5}$ a resemblance between Shrivel, the shaving and hair-brushing dwarf of $\mathrm{Mr}$ Slaughterboard, and Miss Mowcher, the dwarf hair stylist of David Copperfield $;^{6}$ and parallels between Peake's and Dickens's strategies for character naming. ${ }^{7}$ Colin Manlove has gone so far as to claim that 'in some degree the first two books of Peake's trilogy are a re-creation of Bleak House' (p.215). Duncan Fallowell has observed that Peake was 'more stylistically in common with Dickens than with any of his British contemporaries' (p.II72), and Charles Gilbert has contended that 'Peake himself loved Dickens and his writing seems to make the same imaginative bargain with the world' (p.I4).

A fuller analysis of Dickens's influence on Peake seems to be in order, for critics have by and large confined themselves to brief remarks on the subject. Here I examine parallels in their writing styles, artistic convictions, thematic explorations of class, and representations of the city, while taking care not to elide the differences between them. In keeping with previous scholarship, I place more weight on $B H$ than on Dickens's other novels, but branch out where a variety of example seems useful. I also compare Peake with J. R. R. Tolkien, in order to further tease out the affiliations between Peake and Dickens by way of contrast with a third figure. Finally, I will suggest that Peake forged a vital link between Dickensian fiction and a new generation of urban fantasy authors.

Peake's address to the reader provides an illuminating point of departure. By building an opposition between a 'fresh approach to the art of writing' and the extension of 'technical frontiers' on the one hand, and the 'archaic manner' that he ascribed to Dickens and himself on the other, Peake was working towards the formulation of his literary ethos. He knew that his interest lay beyond formal experimentation for its own sake, a thought he expressed again in his introduction to Drawings: 'A drawing may be brilliant in a dozen ways and yet be empty. It may be outlandish, bizarre, and it would seem original, but its heart may be 
missing. It may be, on the face of it, deceptively quiet through lack of graphic experiment, and yet hold some inner life' (pp.7-8). It was not 'graphic experiment', or what he had termed in earlier iterations of the address, 'heterodox language', ${ }^{8}$ that Peake valorised as crucial to the 'inner life' of art. Rather, it was the ability to soar 'off the ground' in order to 'see them [presumably, the fruits of Peake's imagination] face to face'. Paradoxically, he wished to achieve this transcendence by way of the opposite gravitational movement, leaning 'heavily and gladly upon an archaic manner that I love,' in which the Dickensian dimension figured as a 'dark and deathless rabble of long shadows.'

Dark and deathless shadows held a privileged place in Peake's imagination. Shadows are the elemental substance of Gormenghast, which casts 'shadows of time-eaten buttresses, of broken and lofty turrets, and, most enormous of all, the shadow of the Tower of Flints' (TG, p.I5). Then there's the 'perfect shadow' of the Twins' tree, cast upon the wall 'as though engraved with superhuman skill' (TG, p.I37). And the infant Titus is 'suckled on shadows' $(G$, p.7), of course. The shadows of Gormenghast are often the most animated component of its mises-en-scène, as in the Countess's room where 'the missel-thrush made no motion', but 'a ghoul of shadow from under a tall cupboard dislodged itself and moved across the floorboards, climbed the bed, and crawled half way across the eiderdown before it returned by the same route, to curl up and roost beneath the cupboard again' (TG, p.57).

Peake's masterly interplay of motionless figures and dancing shadows has its antecedents in Dickens's 'dark and deathless rabble of long shadows', to use Peake's phrase, not least in $B H$ where, on the decaying aristocratic estate of Chesney Wold, 'the frozen Dedlocks thaw. Strange movements come upon their features, as the shadows of leaves play there' (p.593). Somewhat like Sepulchrave's premonition in Gormenghast's dining hall that he 'will be taken into the immemorial darkness far away among the shadows of the Groans' (TG, p.40I), in Chesney Wold 'the shadow in the long drawing room upon my lady's picture is the first to come, the last to be disturbed. At this hour and by this light it changes into threatening hands raised up, menacing the handsome face with every breath that stirs' ( $B H$, p.594).

Peake's BBC talk, 'The Artist's World' $(A W)$, broadcast shortly after 
the publication of $T G$, extolled 'the shadows, ah, the ancient shadows brooding in corners or under furniture, ominous, menacing, palpable' (p.6). These shadows were part and parcel of what Peake defined in $A W$ as the overall purpose of art, namely to reveal the beauty behind 'the surfaces of things' (p.6). 'As I see it, or as I want to see it, the marvels of the visible world are not things in themselves but revelations to stir the imagination' (p.6) ... to conduct us to amazing climates of the mind, which climates it is for the artist to translate into paint or into words' (p.7). This vision of a dialectic between the material and the spiritual, between the tactile surfaces of concrete objects - 'the rocks, plants, waves, lizards, sunflowers, wallpapers, a fruit, a cat, a child' (p.6) - and the transcendental realm of the imagination that unveils 'a god - perhaps of beauty, or sublime indifference - at any rate, a god' (p.6), chimes with his conscious anchorage in 'the genius of Charles Dickens'.

Peake's unfinished $M r$ Slaughterboard made an explicit connection between Dickens's fiction and the Captain's yearning for an artistic life tethered to the surfaces of books. Slaughterboard allows his blind servant Smear, and only him, to 'fondle' his 'red-leathered Dickens', by virtue of his possessing 'a little of that stuff within which longs for more than material things, ... the semblance of a soul' (p.69). Yet, in paradoxical fashion typical of Peake, it is Smear's fine-tuned sensitivity to the materiality of books, Dickens's fiction not least among them, which emerges most distinctly from his duties during Slaughterboard's reading sessions. As Smear enters the library, 'the smell of the books came to him like a waft of Heaven', and he elicits a quasi-erotic response from the place itself: 'the carpet sank in a kind of voluptuous acceptance of his presence' (p.72). The blind servant recites his Captain's favourite literary works from memory, but Slaughterboard's ritualised evenings in the library demand that Smear first collect the volume to be recited from its place on the shelf, by 'sliding a glass partition aside [before] he ran his fingers over the leather backs' (p.73). His physical possession of the book, at once sensual and sacrosanct, dovetails a metonymical focus on tell-tale hand movements: whereas 'the fingers' of Slaughterboard's 'right hand tapped the table surface delicately', Smear's 'hands were twitching nervously as though longing to hold some coveted treasure' (p.73). 
These observations support Gilbert's suggestion that Peake and Dickens were both imaginatively invested in an 'art of surfaces' (p.I4). Dickens scholars widely concur that the relations between surface and depth, appearances and inner reality, were a source of endless fascination for him. ${ }^{9}$ Dickens excelled at reweaving the fabric of superficial reality by configuring mundane objects and habitual behaviours into outrageously fantastical similes and metaphors, thus suffusing the presumably trivial with a heightened, almost superabundant, sense of meaning. Examples are plentiful; to name a few: in $B H$, 'flakes of soot' are likened to 'full-grown snow-flakes - gone into mourning, one might imagine, for the death of the sun' (p.II); in Dombey and Son (DS), trains arrive at their terminus 'gliding like tame dragons into the allotted corners ... making the walls quake, as if they were dilating with the secret knowledge of great powers yet unsuspected in them' (p.234); and in Our Mutual Friend $(O M F)$, the unremarkable incident of Mr Lammle pouring himself a drink transfigures into the astonishing image of a 'dark lord engaged in a deed of violence with a bottle of soda-water, as though he were wringing the neck of some unlucky creature and pouring its blood down his throat' (p.267).

Peake deployed a similarly hyper-intense visual focus that transformed concrete objects and minute details into marvellous apparitions. His narrative sleight of hand has been elegantly summarised by PierreYves Le Cam: 'Life's mysteries and marvels are made visible. The magic of things, even the tritest ones, is revealed' (p.5). The wine stain on Swelter's uniform thus becomes 'a long red island' (TG, p.33), the candelabrum in the Countess's chamber 'a vast spider suspended by a metal chord' (TG, p.54), and the 'buttresses and outcrops' of Gormenghast buildings 'the hulks of mouldering ships, or stranded monsters whose streaming mouths and brows were the sardonic work of a thousand tempests' $(G$, p.25). These poetics of enlargement, analogy, distortion, and personification were, for Peake, the soul of art, the capacity to see 'in the acorn not only the oak but the whole vegetable universe, and in the whole vegetable universe the vital source of all things' ( $A W$, p.6).

Dickens's and Peake's dense figural writing styles were fuelled by corresponding artistic visions. Dickens held that the role of literature was to unlock the wonder embedded in the quiddity of everyday life. In the 
'Preliminary Word' $(P W)$ for his new journal, Household Words, he articulated a statement of purpose: 'To show to all that in all familiar things, even in those which are repellant on the surface, there is Romance enough, if we will find it out' (p.I). Peake made a strikingly similar declaration about drawing in The Craft of the Lead Pencil ( $L P)$, which came out in the same year as TG: 'Neither be afraid of the unorthodox subject nor in finding delight in the contemplation of commonplace things', he advised. 'Anything, seen without prejudice, is enormous' (p.I). Both authors resisted the generic dichotomy between realism and fantasy, advocating instead a creative licence unhampered by literal-minded notions of verisimilitude. 'It does not seem to me to be enough to say of any description that it is the exact truth,' Dickens contended. 'The exact truth must be there; but the merit or art in the narrator is the manner of stating the truth' (in Forster, II, p.3I3). Peake put it more poetically: 'The quicksands closing on a centaur's head tokens no more of magic than the penny loaf. They both exist' ( $L P$, p.I).

J. R. R. Tolkien, for his part, was dismissive of fantasies that endeavoured to unveil the beauty of 'familiar' and 'commonplace' things. 'To denote the queerness of things that have become trite, when they are seen suddenly from a new angle', he wrote in his seminal essay 'On Fairy-Stories' $(F S),{ }^{10}$ was a 'kind of "fantasy" most people would allow to be wholesome enough', but it had 'only a limited power' (p.I46). ${ }^{11}$ For Tolkien, the highest form of fantasy was 'fairy-stories' (p.II3), which did not 'cause you suddenly to realise that England is an utterly alien land' (p.I47), but rather transported the reader into 'a Secondary World' whose 'inner consistency of reality' was so immersive that it temporarily supplanted the reader's sense of his own reality (p.I40). Tolkien contended that the Secondary Worlds of fairy-stories needed to be self-contained and insulated, excluding 'marvels to be seen in this mortal world in some region of our own time and space' (p.II5). The effect of this isolationist fantasy, he readily admitted, was reactionary: 'I do not think that the reader or the maker of fairy-stories need even be ashamed of the "escape" of archaism: of preferring not dragons but horses, castles, sailing-ships, bows and arrows; ... [to] progressive things like factories' (p.I50). And he cited Christopher Dawson's radically anti-modern claim that 'the rawness and ugliness of modern European life ... is the sign of 
a biological inferiority, of an insufficient or false reaction to environment' $(F S$, p.I50). Everything that was wrong with modern life, in Tolkien's view, could be laid squarely at the feet of the Victorian Age: "Why should we not escape from or condemn the "grim Assyrian" absurdity of top hats, or the Morlockian horror of factories?' (p.I50), he pointedly asked.

Dickens's politics has been a subject of longstanding debate among scholars, but there is ample evidence to suggest that he was averse to anti-Victorian medievalism of the kind promulgated by Tolkien. Odious characters such as Mrs Skewton in DS and the red-faced gentleman in The Chimes, as well as Dickens's satirical pieces, 'The Fine Old English Gentleman' and the 'Threatening Letter to Thomas Hood', point to his antipathy towards those who pined for 'the fine old English Tory times'. ${ }^{12}$ Indeed, Mrs Skewton is an explicit caricature of conservative medievalists, waxing sentimental over 'the Middle ages': 'Such charming times! ... So full of Faith! So vigorous and forcible! So picturesque! So perfectly removed from commonplace!' (DS, p.407).

Rather than offering escape into an idealised distant past, Dickens directed his writing towards the illumination of the hidden splendour concealed beneath the outward ugliness of the contemporary industrial world: 'The mightier inventions of our age are not, to our thinking, all material, but have a kind of souls in their stupendous bodies which may find expression in Household Words,' he wrote in PW, proposing communion with no less a fixture of modern life than 'the towering chimneys ... spurting out fire and smoke upon the prospect' (p.I).

From Peake's meditations on drawing, one may easily surmise that his inclinations lay with Dickens rather than Tolkien. His comments on his writing, however, complicate the case. Take, for example, an excerpt from his letter to Gordon Smith, outlining his thoughts about TG:

I feel that what I'm 'after' has to a large extent been forgotten while I wrote. What was I after anyway? I suppose, to create a world of my own in which those who belong to it and move in it come to life and never step outside into either this world of bus queues, ration books, or even the upper Ganges - or into another imaginative world. I mean that the mood should be always, although I hope varied from chapter to chap- 
ter - yet consistently, say, Gryphon, and not Bulldog, Gazelle or even Gargoyle. (24 October 1943, in Smith, p.I03)

Taken at face value, this letter seems to indicate Peake's intention of creating a closed fictional realm that tallies closely with Tolkien's contemporaneously developed theory of Secondary Worlds. The impression is reinforced by Peake's specific rejection of elements from everyday life, namely 'bus queues' and 'ration books'. Towards the end of the letter, however, the apparent parallels with Tolkien are cast into doubt by the image of a gryphon, Peake's monster of choice for the embodiment of his novel's otherworldliness. A gryphon is rather different from Tolkien's graceful 'folk of Faërie' who 'put on the pride and beauty that we would fain wear ourselves' ( $F S$, p.II3). It is a chimera made up of the unlikely combination of lion and eagle. ${ }^{13}$ His emblematic use of the gryphon thus intimates a more ungainly realm than Tolkien's Faërie.

The gryphon's piecemeal corporeality carries over to the timeworn stones of Gormenghast, with its Tower of Flints 'patched unevenly with black ivy' and protruding 'like a mutilated finger from among the fists of knuckled masonry' (TG, p.I5). The gritty texture of these descriptions has far more in common with $B H$ 's Chesney Wold, 'that ancient house, rooted in that quiet park, where the ivy and the moss have had time to mature, and the gnarled and warted elms, and the umbrageous oaks, stand deep in the fern and leaves of a hundred years' (p.4I6), than with Tolkien's glamorous, glittering edifices. Compare Gormenghast's Tower of Flints to Gondor's 'Tower of Ecthelion' in The Lord of the Rings (LOTR), which 'shone out against the sky, glimmering like a spike of pearl and silver, tall and fair and shapely' (p.75I). The contrasts in colour, shape, and atmosphere between Peake's and Dickens's edifices on the one hand, and Tolkien's on the other, can be interpreted as metonymically indicative of the differences between their fictional worlds - the former evince an uneven, abrasive, implacable bulk of architecture, the latter evoke rather a sanitised, smooth, immaculately polished monolith.

Gormenghast's rough-edged epistemological surface likewise accommodates a Dickensian theme beyond the pale of LOTR, namely class stratification and its severe consequences for Haves and Have-Nots alike. 
Gormenghast may be a world away from 'bus queues' and 'ration books', but it boldly implies the perennial gulf between the over-privileged and the dispossessed. The opening paragraph of $T G$ describes the most wretched of all Gormenghast's locales, the Outer Dwellings. These ramshackle hovels spread from the castle 'like an epidemic around its outer walls' (p.15), their residents an 'all-but forgotten people' plagued by premature aging and bitter enmities (p.r.). This Gothic shanty town calls to mind the personified slum of $B H$, nicknamed 'Tom-all-alone's', where 'tumbling tenements contain, by night, a swarm of misery' (p.236), people are rarely known 'by any Christian sign' (p.33I), and wanton neglect unfailingly 'propagates infection and contagion' (p.654). Moreover, both the Outer Dwellings and Tom-all-alone's have a devastating effect on the centres of power that have marginalised them. Tomall-alone's is home to Jo, the crossing sweeper beautifully drawn by Peake, ${ }^{14}$ who unwittingly becomes key to the exposure of Lady Dedlock's secret past and the consequent downfall of the Dedlock family. Analogously, the Dweller Keda becomes Titus's wet nurse, and as Manlove observes (though he promptly dismisses his own insight), 'it could be argued that Titus sucked in the lust for freedom with her milk' (p.236). Keda's illegitimate daughter, 'The Thing', plays a vital role in Titus's decision to leave Gormenghast, ${ }^{15}$ thus effectively ending the Earldom of House Groan.

The first close-up view of the city in Titus Alone (TA) likewise foregrounds the lower stratum of its society. Peake introduces an array of scruffy figures: the fishermen labouring on the shore of the river, 'some on foot hugging themselves in the cold; some in ramshackle muledrawn carriages' (p.I4). The eccentric zoo-keeper Muzzlehatch drives down to 'benefit whatever beggars wished to climb into the mouldering stern' of his car (p.I5). Shortly thereafter, 'two beggars' help rescue Titus from his pursuers, presumably for no better reason than that he seems 'as ragged a creature as themselves' (p.r. ). The recurrent foregrounding of the under-privileged at the beginning of both $T G$ and $T A$ challenges the pervasive belief among critics that Dickens's influence on Peake ended with $G$, and that $T A$ should be considered a separate case whose literary debts are of a different order. Manlove maintains that 'the first two books of Peake's trilogy' can be read as 'a re-creation of Bleak House' 
(p.215), whereas 'Titus Alone may well have owed much to the book which was also the source of Orwell's Nineteen Eighty-Four - Yevgeny Zamyatin's We' (p.216). Tanya Gardiner-Scott's study, Mervyn Peake; The Evolution of a Dark Romantic, posits that Peake 'is closer to Dickens in the first two Titus books and dystopian fiction in the third' (p.2).

This line of argument develops from the startling change in style from $T G$ and $G$ (which are governed by the 'archaic manner' that Peake loved - an atmosphere of timeless decay and a ponderous accumulation of detail) to TA's accelerated staccato pace and science-fictional urban setting. But to induce from this stylistic shift that Dickens's influence on Peake had abated is to underestimate both Dickens and Peake. The opposition erected by critics between Dickens's influence on $T G$ and $G$, and the influence of dystopian writers such as Orwell and Zamyatin on $T A$, reveals itself as a false dichotomy once we take stock of the pervasiveness of Dickens's legacy, which played a crucial part in shaping the dystopian fiction to which he is putatively opposed, most overtly via H. G. Wells. Both Orwell and Zamyatin expressly remarked upon Dickens's influence on Wells, and upon Wells's influence in turn on their own writing, ${ }^{16}$ and scholars of dystopian fiction have done important work fleshing out these affiliations. ${ }^{17}$

Moreover, Maurice Collis claimed that Peake had always intended for Titus to go out into the world,${ }^{18}$ which would indicate that his departure from Gormenghast was planned as an enlargement of the scope of $T G$ and $G$ rather than an ontological rupture. In this vein, Peake's decision to lead Titus out of Gormenghast and into the city can be read as a rejection of Tolkienesque escapism in favour of a more Dickensian urban vision. If Titus were indefinitely confined to Gormenghast, thereby confirming the Countess's assertion that 'there is nowhere else' ( $G$, p.5IO), Peake would have been yielding to the temptation of escape into a hermetic Secondary World. Titus's departure is thus anti-escapist in itself, but the effect is redoubled by his emergence into a specifically urban environment. Clute and Grant's monumental Encyclopedia of Fantasy $(E F)^{19}$ suggests that contrary to Tolkien's Secondary Worlds, which are 'not bound to mundane reality' (p.847), cities are the 'natural venue' for fantasies that 'tend to Crosshatch the mundane world with Otherworlds' (p.976). ${ }^{20}$ According to Clute, urban fantasy is by definition 
'significantly about a real city' (p.975), its two dominant models being Dickens's London and Eugène Sue's Paris. ${ }^{21}$ Hence, for Peake to have transplanted Titus into a city that, as Gardiner-Scott has remarked, resembles from above 'an aerial view of London, England' defamiliarised by its placement on a mountainside (p.217), was for him to have effectively aligned himself with Dickensian London as against the reactionary sequestration advocated by Tolkien.

It may be relevant here that neither Peake nor Dickens was a born Londoner. Peake was born in China and moved with his family to Wallington, Surrey, at the age of eleven, and began commuting to London for art school in $1929 .{ }^{22}$ The Dickens family moved from Chatham to London in I822, when Dickens was ten. ${ }^{23}$ John Forster wrote that Dickens 'managed gradually to transfer to London all the dreaminess and all the romance with which he had invested Chatham' (I, p.I5). The same could perhaps be said of Peake, who redirected the dreaminess and romance of his imagination from China to England, or from Gormenghast to the unnamed city of TA. Moreover, both Dickens and Peake displayed a lasting sense of wonder at the spectacles of London, which may have been rooted in their analogous fresh impressions of the city in their youth. 'We never have outgrown the whole region of Covent Garden,' Dickens wrote in a piece titled 'Where We Stopped Growing'; 'we preserve it as a fine, dissipated, insoluble mystery' (p.362). Peake gave voice to a similar feeling of reverence in his remarkably Dickensian prose sketch, 'London Fantasy' $(L F)$, where he asserted that 'in the weird creatures that make up this dark hive called London', one may find 'a cavalcade hardly to be suffered for the very endlessness of its inventive fantasy' (p.3).

For Peake, more than for Dickens, however, the unfathomability of 'this dark hive called London' posed a danger to the sensitive mind. 'There is no end to it,' the narrator of $L F$ exclaims with a touch of hysteria, 'the Invention is so rapid, various, profluent' (p.6), until finally 'each desperate moment, clutching Entirety, sinks with a smouldering fistful of raw plunder; sinks into nullity' (p.7). These phrases recur almost verbatim, though shifted into the past tense, with reference to the crowd of vagrants assembled to watch Titus battle Veil in the Under-River: 'There was no end to it. The inventiveness of it was so rapid, various, profluent. 
Each movement sank away, sank with a smouldering fist-feel of raw plunder: sank into nullity' (pp.I32-3). Regardless of whether it was intentional, this transposition from a sketch about the fantastical qualities of London to the subterranean underworld beneath the surface of $T A$ 's city, lends further credence to the supposition that the city constitutes a re-imagining of London refracted through the dreamscapes of Peake's artistic vision. However fictionalised and estranged, Peake's London shines through $T A$ 's city as a nexus of 'inventive fantasy', as exhilarating as it is perilous.

Scholars have pointed out that, through its cars, police force, aeroplanes, scientists, bureaucracy, and surveillance technology, the city of $T A$ ushers in the modern world that was so conspicuously absent from the previous novels. But science-fictional trappings aside, Peake's first and only novel of the city drew widely upon the imagery and themes of his favourite urban book, Bleak House. In the back of Muzzlehatch's car, speeding 'away down tortuous alleys still wet and black with the night shadows, Titus became aware of the nature of the city into which he had drifted like a dead branch' (pp.I8-I9). His discovery shares more than a passing resemblance (minus the speed) to Esther Summerson's account of her first arrival in London by coach: 'We drove slowly through the dirtiest and darkest streets that ever were seen in the world (I thought), and in such a distracting state of confusion that I wondered how the people kept their senses' $(B H$, p.37). Likewise, the London of $B H$ and the city of $T A$ are both wreathed in flame at dusk and dawn. The afterglow of a sunset in $B H$, contrasted with 'a lurid glare' that looms over London, conjures the mirage of 'an unearthly fire, gleaming on all the unseen buildings of the city, and on all the faces of its many thousands of wondering inhabitants' (p.450). A sunrise over Peake's city appears to 'cut its way up as though with a razor's edge, and immediately the boats and their crews and the cormoranteers and their bottle-necked birds, and the rushes and the muddy bank and the mules and the vehicles and the nets and the spears and the river itself, became ribbed and flecked with flame' (p.I7).

Both novels emphasise the disparity between the gentrified areas of their city and the blighted slums. In $B H$ 's London, the Dedlocks' house in town, which at its best beckons 'as warm and bright as so much state 
may be' (p.422), contrasts with Tom-all-alone's, where 'ruined shelters have bred a crowd of foul existence' that 'coils itself to sleep, in maggot numbers, where the rain drips in' (p.236). In TA's city, the 'fantasies of glass and metal' that circumscribe the marble-paved arena of its most opulent district, jar sharply with 'the tortuous, poverty-stricken town' of 'the district of Muzzlehatch' (p.32), not to mention the Under-River, 'kingdom of the outcasts; the fugitives; the failures; the mendicants; the plotters; a secret world with a roof that leaked eternally' (p.III). Indeed, the Under-River discloses the ease with which the downtrodden are excluded from the purview of the more fortunate city-dwellers, through a narrative intervention that channels Dickens the reformer as well as the fiction writer:

To those ignorant of extreme poverty and of its degradations; of pursuit and the attendant horrors; of the crazed extremes of love and hate; for those ignorant of such, there was no cause to suffer such a place. It was enough for the great city to know and to have heard of it by echo or by rumour and to maintain a tacit silence as dreadful as it was accepted.

(TA, p.II2)

This extraordinary passage readily calls to mind the most wretched areas of Dickens's London - Tom-all-alone's that is 'avoided by all decent people' (p.235), and Jacob's Island in Oliver Twist (OT): 'the filthiest, the strangest, the most extraordinary of the many localities that are hidden in London, wholly unknown, even by name, to the great mass of its inhabitants' (p.338). It likewise reverberates with Dickens's exhortations to acknowledge the disenfranchised of Victorian society, notably through the characters of Jo in $B H$ and Betty Higden in $O M F$.

Dickensian London is visibly evoked in $T A$ at the trial where Titus stands accused of 'vagrancy, damage, and trespass' (p.76). The Magistrate who presides over this trial embodies a light-hearted tribute to the Lord High Chancellor of $B H$, musing as he does that 'he was a symbol. He was the Law. He was Justice. He was the wig he wore' (p.8I). Throughout the trial he betrays an incompetence that cements his affinity with Dickens's High Chancellor, whose benighted intellect is aptly captured in his habit of staring 'into the lantern that has no light in it' (BH, p.I2). But where Dickens's parody of the legal system expressed his outrage at the 
suffering caused by its dysfunctional practices, Peake seemed to be looking back at this ineptitude with a degree of nostalgia. Having witnessed at first hand the aftermath of the systematic mass-murder in the death camps, Peake was far more tolerant of inefficiency as a humane alternative. At the trial, Muzzlehatch compares Inspector Acreblade - who resembles the ridiculous Bow Street Runners of OT far more than the shrewd Inspector Bucket of $B H$ - with the Orwellian helmeted pursuers who wield the true executive power in the city, to the manifest advantage of the former: 'He, Muzzlehatch, had also picked out Inspector Acreblade (a pleasant change from the tall enigmas), for there could be nothing more earthy than the Inspector, who believed in nothing so much as his hound-like job, the spoor and gristle of it: the dry bones of his trade' (p.79). Thus, while for Tolkien the Victorian Age was to blame for modernity, for Peake it expressed a down-to-earth, clumsy, but honest pragmatism, a solid core of humanity woefully absent from the soulless expertise of the modern agents of state authority.

At the heart of both $B H$ and $T A$ lies an enquiry into the secret connections that bring together the decaying edifice and the sprawling city. Ruminating upon the invisible threads that tie wealth to poverty across Chesney Wold and London, Dickens's narrator ponders: 'What connexion can there be, between the place in Lincolnshire, the house in town, the Mercury in powder, and the whereabouts of Jo, the outlaw with the broom' ( $B H$, p.235). Faced with 'a world that appeared to have no reference to his home and which seemed, in fact, supremely self-sufficient' (TA, p.32), Titus cannot but wonder about Gormenghast and the city: 'Were they coeval; were they simultaneous? These worlds; these realms - could they both be true?' (p.32). The answers offered by each novel, however, are crucially different. In $B H$, Chesney Wold and London are linked by the hopelessly convoluted web of the Law, incarnated in the Jarndyce and Jarndyce lawsuit that entangles every character and every event in the narrative, and converges upon the Court of Chancery at the heart of the London fog, 'which has its decaying houses and its blighted lands in every shire' (p.I3).

Gormenghast and $T A$ 's city, in contrast, are not connected by a concrete socio-political force as in $B H$, but rather more tenuously linked by Titus's groping mind. Once he leaves home, Titus's imaginative powers 
become embedded in his mental image of Gormenghast, which he expressly calls 'the kingdom in my head' (p.195). He carries this mental image with him into the city, surrounding him with an aura of mystery that attracts a range of city dwellers from Muzzlehatch and Juno to the three vagrants from the Under-River. But the kingdom in his head often appears more real to Titus than the city in which he has temporarily settled, leaving him constantly wondering, 'Who are these people? What are these happenings?' (p.I95). The connection between Gormenghast and the city thus appears fragile at best, and Peake's city accordingly lacks the solidity of Dickens's London. The two cities' varying degrees of substantiality may be attributed, among other causes, to the historical differences between Victorian and mid-twentieth-century London.

Victorian London, for all its social injustices that Dickens assiduously brought to public attention, was the capital of the British Empire and thus, in the eyes of many, the focal point of the western world. When Peake wrote TA in the I950s, however, London was struggling to rebuild itself after the Blitz, and the British Empire had been reduced to its last vestiges. The immigrant author V. S. Naipaul, who had come to London in 1950 expecting to behold 'the London I had got from Dickens' (p.I22), was thus destined to find 'a city that was strange and unknown' (p.I23). Indeed, Naipaul's arrival was part of that change - I950s London was a city in transition, no longer an imperial power, but taking its first steps towards becoming a new kind of metropolis, a locus of immigration, multiculturalism, and multinational exchange in an increasingly globalised world. As Jerry White's London in the Twentieth Century has shown, 'the Londoner was remade in the second half of the twentieth century: an "alloy of the people of Britain" in the 1940s, an alloy of the people of the world just forty years later' (p.I30). According to White, 'this was a change irrevocably established in just a decade and a half, between the mid-I950s and the late 1960s' (p.I3I). Peake had arguably intuited this transformation, which led him to configure the city of $T A$ as an unstable, at times insubstantial, site of a world-shattering confrontation of difference, an encounter between modern urbanites and the abdicated Earl of Gormenghast who strikes them as 'something as mysterious and elusive as a ghost' ( $\mathrm{p} .89)$. For each side of this encounter, then, the Other appears unreal, a disassociation only overcome by 
degrees, primarily through the burgeoning friendship between Titus and Muzzlehatch.

The case can be made, accordingly, that the controversial ending of $T A$ dovetails well with both Peake's historical moment and the tenor of the novel. By sending Titus down a track 'that he had never known before' (p.263), Peake anticipated the opening up of fictional and sociopolitical space in a postcolonial age where, to borrow Yeats's immortal phrase, 'the centre cannot hold'. ${ }^{24} \mathrm{He}$ thus renewed his refusal to lock Titus in a Tolkienesque hermetic world, and moved beyond it to likewise reject the implicit assumption of Dickensian fiction that all narrative roads lead to London. Hence, it is the villainess of TA, Cheeta, who undermines Titus's sense of continuous and unbound space by collapsing Gormenghast and the city into a false spectacle that is neither one nor the other: 'He thinks that to move about is to change places', she declaims. 'He does not realize that he is treading water' (p.23I). Here Cheeta is echoing another woman who had tried to control Titus, his mother; she told him: 'You will only tread a circle, Titus Groan' (G, p.5IO). Both women sought to persuade him that his is an insular world, where space either folds in upon itself or operates as a closed circuit; both are proved wrong by the narrator's panoramic sweep over 'bonewhite, cave-pocked, barren mountains, the fever-swamps and jungles to the south, the thirsty lands, the hungry cities, and the tracts beyond of the wolf and the outlaw' (TA, p.35). Moreover, when Titus defies them and chooses the road not taken, he is heeding the advice given him by Muzzlehatch, his staunchest friend from the city: 'Get on with life. Eat it up. Travel. Make journeys in your mind. Make journeys on your feet. To prison with you in a filthy garb! To glory with you in a golden car! Revel in loneliness. This is only a city. This is no place to halt' (p.ro7).

Titus's journey is left open-ended on the path newly taken, and we cannot say exactly where his travels were to have led him. But one thing seems assured - Peake's legacy has never halted. The call to make journeys in your mind has been taken up by a stable of writers that Peake's admirer Michael Moorcock has termed 'the modern school of urban fantasy' whose 'heroes include the likes of Mervyn Peake and Clark Ashton Smith' ('Facing the City', p.I83). Their fables of the fantastic city, Moorcock asserts, can be read as 'the gritty opposite of the Tolkien 
school,' by virtue of their appeal 'to readers not merely seeking escape but looking for versions of their own experience' (p.I83). The contemporary authors who most openly celebrate Peake's influence on their work are accordingly Moorcock and China Miéville, two luminaries of urban fantasy, both of whom have called for a reappraisal of $T A .^{25}$

Dickensian influences are also discernible in their urban fantasy novels ${ }^{26}$ but Miéville has downplayed Dickens's impact by claiming that any such allusions have made their way into his writing via Peake. ${ }^{27}$ From this point of view, one may venture to suggest that across the tangled web of intertexts, transpositions, and inspirations that make up the history of any genre, Dickens may be no less indebted to Peake than Peake was to Dickens. Peake ensured that Dickens's shadow remained long and deathless, by adding his own shades of darkness and light to the enduring literary tradition of fantastical reimaginings of London, that city which both authors had recreated with 'all the dreaminess and all the romance' of their inimitable imaginations.

(C) Hadas Elber-Aviram 2015

\section{Notes}

I This word is extremely difficult to make out. After several attempts, I can say with a high degree of certainty that it reads 'rabble', as the first three letters emerge as 'rabb' when compared against other words in Peake's handwriting, and the final letter forms either an 'e' or a ' $c$ ', with only the 'l' conjectural.

2 I am most grateful to Peter Winnington, who referred me to this address and deciphered the better part of its contents well before I approached the matter. He has generously allowed me to build upon his work for this article. For that and much more, my warm and humble gratitude.

3 Reproduced with the kind permission of the Mervyn Peake Estate and The British Library Board.

The source can be examined in The British Library, in a manuscript listed as “'Ideas for Book Two" (Titus Groan chapters 60-6I),' MS $8893 \mathrm{I} / \mathrm{I} / 3 / 9$, notebook viii. Access to the notebook itself has been restricted, but a scan of its pages is freely available. For the scanned image of the address, see the file with the suffix '_foorr'. For the scanned image of the false starts, three consecutive paragraphs on a single page, see the file 
with the suffix 'ffoorv'. In the above quote, the minor additions in square brackets have been made by Winnington and myself, for greater clarity.

4 For reproductions of Peake's illustrations for $B H$, see Sketches from Bleak House. Note that Peake also made the cover drawing for Humphry House's The Dickens World (2nd ed. 1960).

5 Winnington, Voice of the Heart, p.I74.

6 Winnington, Vast Alchemies, p.8I.

7 Winnington, Vast Alchemies, pp.85-6.

8 In two of the three earlier attempts to compose the address, Peake used the phrase 'heterodox language' in conjunction with the phrase that carried over to the final version, 'fresh approach to the art of writing'.

9 See, for example, Juliet John's splendid study, Dickens's Villains, particularly pp.II4-2I; Grahame Smith, Dickens and the Dream of Cinema, pp.36, 7I-3; Chris Louttit, Dickens's Secular Gospel, pp.I0-I4; Elaine Freedgood, 'Realism, Fetishism, and Genocide', in her study, The Ideas in Things, pp.8I-IIO.

Io Tolkien's 'On Fairy-Stories' was developed from the Andrew Lang Lecture Tolkien delivered at the University of St. Andrews (1939). It was expanded into essay form for publication in Essays Presented to Charles Williams (1947), revised again for the volume Tree and Leaf (1964), and appeared in its final version in The Monsters and the Critics (1983). This article uses the final version of 1983 . For a comprehensive analysis of the essay across its various stages of composition, see Verlyn Flieger and Douglas A. Anderson, Tolkien On Fairy-stories.

II Tolkien's disdainful remarks refer to what he calls 'Mooreffoc, or Chestertonian Fantasy' after Dickens's disciple G. K. Chesterton, but Tolkien is clearly addressing a strain of fantasy that Chesterton developed from Dickens, and moreover, the example Tolkien showcases is lifted from Dickens's autobiographical fragment: 'Mooreffoc is a fantastic word, but it could be seen written up in every town in this land. It is Coffee-room, viewed from the inside through a glass door, as it was seen by Dickens on a dark London day' (FS, p.I46). Tolkien's foregrounding of the Mooreffoc episode in Dickens's early life incidentally highlights another parallel between Dickens and Peake. Peake named Rottcodd, the curator of Gormenghast's Hall of the Bright Carvings, after seeing 
the word 'doctor' on the windscreen of his father's car: from inside the vehicle it reads 'rotcod' (see Vast Alchemies, p.I35). Dickens's autobiographical fragment was reproduced in Forster's Life of Dickens, vol. I, pp.20-36, with the 'Mooreffoc' episode on pp.26-7. The episode was eloquently discussed in Chesterton's Charles Dickens, p.42.

I2 Dickens, 'The Fine Old English Gentleman', pp.29-3I (repeated as a refrain).

I3 In his illustration of a gryphon for Lewis Carroll's Alice in Wonderland, Peake hybridised it still more by adding a pair of dainty human arms and hands, a bold use of artistic licence considering Carroll's emphasis on the gryphon's 'paws'. See Lewis Carroll, Alice's Adventures in Wonderland \& Through the Looking Glass; with sixty six illustrations by Mervyn Peake, p.79. The gryphon's 'paws' are mentioned on pp.76, 77, \& 80.

I4 Reproduced in Sketches from Bleak House, p.37, and on the front cover of Writings and Drawings.

I5 The narrator explicitly asserts that Titus's 'longing to escape had been fanned by his passion for the "Thing". Without her he would have never dared to do more than dream of insurrection' (G, p.506).

I6 See Orwell's 'Charles Dickens' (1940), 'Wells, Hitler and the World State' (194I), and 'The True Pattern of H. G. Wells' (1946), and Zamyatin's 'On Language' (1919-20) and 'H. G. Wells' (1922).

I7 See Gordon Beadle, 'George Orwell and Charles Dickens'; Wayne Warncke, 'George Orwell's Dickens'; Philip Rogers, 'Dystopian Intertexts: Dickens's Hard Times and Zamiatin's We'; and Emily Finer, 'Dickens in Twentieth-Century Russia'. My own doctoral dissertation (in progress) examines a tradition of urban fantasy that concatenates Dickens, Wells, Orwell, Peake, and China Miéville.

I8 Collis recalled a meeting with Peake on I7 May 195I, when 'he had started on the third volume of the story ... [that] deals with the adventures of Titus Groan in the world' (p.37). To this Collis adds: 'I remember when I first met Peake in 1942 or thereabouts ... he told me that he was contemplating these books and sketched the story' (p.37).

I9 The $E F$ has been digitalised and revised online over the years. For the most up-to-date version, see $<$ http://sf-encyclopedia.uk/fe.php $>$ [accessed 23 Nov. 20I4]. 
The following abbreviations indicate different entries in the $E F$, all of which were written by John Clute: $U F$ for 'Urban Fantasy', in $E F$, pp.975-6, or <http://sf-encyclopedia.uk/fe.php?nm=urban_fantasy> [accessed 23 Nov. 20I4]; SW for 'Secondary World', in EF, p.847, or $<$ http://sf-encyclopedia.uk/fe.php?nm=secondary_world> [accessed 23 Nov. 20I4]; JRR for 'Tolkien, J(ohn) R(onald) R(euel)', in EF, pp.950-5, or <http://sf-encyclopedia.uk/fe.php?nm=tolkien_j_r_r> [Accessed 23 Nov. 20I4]; $C D$ for 'Dickens, Charles (John Huffham)', in EF, pp.268-9, or $<$ http://sf-encyclopedia.uk/fe.php?nm=dickens_charles $>$ [Accessed 23 Nov. 20I4].

20 Granted, sometimes the cities of urban fantasy are so strange and immersive that they may be deemed Secondary Worlds in their own right, but these too are of a different order from Tolkien's Faërie, by dint of an epistemological ambiguity quite unlike the ontological transparency of Middle Earth. Where Tolkien's Secondary Worlds must above all induce 'Secondary Belief' and accordingly be 'legible' (JRR, pp.95I-3), urban fantasies are 'told from within, and, from the perspective of characters acting out their roles, it may be difficult to determine the extent and nature of the surrounding Reality' (UF, p.975). On Secondary Belief, see also $F S$, p.I32.

2I See $U F$, p.975, and $C D$, p.269.

22 Biographical information from Winnington, Vast Alchemies; Gilmore, $A$ World Away; and Smith, Mervyn Peake.

23 There are numerous biographies of Dickens, from as early as Forster's Life of Dickens (I, I87I), to as recently as Michael Slater's The Great Charles Dickens Scandal (20I4). Two excellent biographies published in the last few years are Robert Douglas-Fairhurst, Becoming Dickens (20II), and Slater, Charles Dickens (2009).

24 From W. B. Yeats, 'The Second Coming' (1920), p.I87.

25 Moorcock's 1983 'Preface' to Gilmore's A World Away avowed that Peake 'certainly had considerable influence on what I think is my own best work' (p.xiii). Moorcock likewise wrote the introduction to the recent German edition of TA (20II), where he argued that 'in many ways Titus Alone is for me the most interesting of the three books Mervyn Peake wrote concerning the young Lord of Gormenghast' (p.257).

In the Acknowledgments in Perdido Street Station (2000), China Miéville 
wrote: 'to M. John Harrison, and to the memory of Mervyn Peake, my humble and heartfelt gratitude. I could never have written this book without them.' He likewise stated in an online interview (2000) that 'the nicest thing anyone ever said about Perdido Street Station was that it read like a fantasy book written in an alternate world where the Gormenghast trilogy rather than Lord of the Rings was the most influential work in the genre.' Miéville composed the introduction to the most recent collected edition of the Gormenghast trilogy, where he paid special tribute to $T A$ as 'that last, so-strange, scandalously neglected volume, changeling among changelings' (p.ix). For more on Miéville and Peake, see Alice Mills, 'Inspiration and Astonishment'.

26 For Dickens's influence on Moorcock, see Angela Carter's 'Introduction' (199I) to Death is no Obstacle, pp.xi-xii. Moorcock himself stated in an interview in the same book: 'People have made comparisons between Mother London and Ulysses, but it's not true. I'm still a popular novelist. My role model can't be James Joyce; it has to be Charles Dickens' (p.98). For Dickens's influence on Miéville, see Carl Freedman, 'Perdido Street Station by China Miéville (2000)', p.I20I; M. Keith Booker and AnneMarie Thomas, 'China Miéville, Perdido Street Station [2000]', p.3II; and my article, 'The Labyrinthine City: Bleak House's Influence on Perdido Street Station'.

27 In a 2003 interview, the interviewer Joan Gordon told Miéville: 'Your names - of places, people, etc. - are very evocative, Dickensian'. Miéville replied that 'they're probably more Peakeian than Dickensian, really' (p.369).

\section{Sources}

Beadle, Gordon. 'George Orwell and Charles Dickens: Moral Critics of Society', Journal of Historical Studies II.4 (Winter 1969-70): 245-55.

Booker, M. Keith and Anne-Marie Thomas. 'China Miéville, Perdido Street Station [2000]', in The Science Fiction Handbook. West Sussex, UK: WileyBlackwell, 2009. pp.306-I3.

Collis, Maurice. 'I7 May 1951', in Louise Collis (ed.), Maurice Collis Diaries: 1949-1969. London: Heinemann, 1977. pp.36-7.

Carroll, Lewis. Alice's Adventures in Wonderland \& Through the Looking Glass; 
with sixty six illustrations by Mervyn Peake. London: Methuen, 1978 [1865; illustrations 1946].

Chesterton, G. K. Charles Dickens: A Life. London: Methuen, 1956 [1906].

Clute, John and John Grant (eds.). The Encyclopedia of Fantasy. New York: St. Martin's Griffin, 1999 [1997]. The EF has been digitalised and revised online over the years. For the most up-to-date version, see $<$ http://sf-encyclopedia.uk/fe.php> [Accessed 23 Nov. 2014].

Dickens, Charles. 'A Preliminary Word', Household Words (March 30, I850): pp.I-2.

- Bleak House. Oxford: OUP, 1999 [1852-53].

- Dombey and Son. Oxford: OUP, 200I [I846-48].

- Oliver Twist. Oxford: OUP, 1966 [1837-39].

- Our Mutual Friend. Oxford: OUP, 198I [1864-65].

— The Chimes. London: Nottingham Court Press, 1983 [1844].

- 'The Fine Old English Gentleman', in Poems and Verses by Charles Dickens. Newcastle upon Tyne: Cambridge Scholars Publishing, 2009 [I84I]. pp.29-3I. Originally published in The Examiner (August I84I).

- 'Threatening Letter to Thomas Hood, from an Ancient Gentleman', in Arthur Waugh, Hugh Walpole, Walter Dexter, and Thomas Hatton (eds.), The Nonesuch Dickens: Collected Papers. Vol. I. Bloomsbury: The Nonesuch Press, 1937 [1844]. pp. 23-4.

'Where We Stopped Growing', Household Words 6.I45 (I January I853): pp.36I-3.

Douglas-Fairhurst, Robert. Becoming Dickens; The Invention of a Novelist. London; Cambridge, Mass.: Harvard University Press, 20II.

Elber-Aviram, Hadas. 'The Labyrinthine City: Bleak House's Influence on Perdido Street Station', English: the Journal of the English Association 61.234 (Autumn 20I2): pp.267-89.

Fallowell, Duncan. 'Peake, Mervyn Laurence; 19II-68; English novelist and artist', in Justin Wintle (ed.), New Makers of Modern Culture. Vol. 2, L-Z. London and New York: Routledge, 2007. pp.II7I-3.

Finer, Emily. 'Dickens in Twentieth-Century Russia', in Michael Hollington (ed.), The Reception of Charles Dickens in Europe. Vol. I. London; New Delhi; New York; Sydney: Bloomsbury, 2013. pp.I03-20.

Flieger, Verlyn, and Douglas A. Anderson (eds.). Tolkien On Fairy-stories. London: HarperCollins, 2008. 
Forster, John. The Life of Charles Dickens. Vols. I and II. London: Chapman and Hall, I9II [I, I87I; II, I872; III, I873].

Freedgood, Elaine. The Ideas in Things; Fugitive Meaning in the Victorian Novel. Chicago; London: University of Chicago Press, 2006.

Freedman, Carl. 'Perdido Street Station by China Miéville (2000)', in Gary Westfahl (ed.), The Greenwood Encyclopedia of Science Fiction and Fantasy; Themes, Works, and Wonders. Vol. 3. Westport: Greenwood Press, 2005. pp.I200-02.

Gardiner-Scott, Tanya J. Mervyn Peake; The Evolution of a Dark Romantic. New York; Bern; Frankfurt am Main; Paris: Peter Lang, 1989.

Gilbert, Charles. 'Mervyn Peake and Memory',Peake Studies 5.4 (1998): pp.520.

Gilmore, Maeve. A World Away; A Memoir of Mervyn Peake. London: Methuen, 1983 [1970].

House, Humphry. The Dickens World. Second edition. London: OUP, 1960 [194I].

John, Juliet. Dickens's Villains; Melodrama, Character, Popular Culture. Oxford: OUP, 200I.

Le Cam, Pierre-Yves. 'Peake's Fantastic Realism in the Titus Books', Peake Studies 3.4 (1994): pp.5-15.

Louttit, Chris. Dickens's Secular Gospel; Work, Gender, and Personality. New York; London: Routledge, 2009.

Manlove, Colin Nicholas. Modern Fantasy: Five Studies. Cambridge: CUP, 1975.

Miéville, China. 'Fantasy and revolution: an interview with China Miéville', International Socialism Journal 88 (2000). < http://pubs.socialistreview index.org.uk/isj88/newsinger.htm $>$ [Accessed I3 Nov. 20I4].

—_ 'Introduction', in The Illustrated Gormenghast Trilogy. London: Vintage Books, 20II. pp.ix-xii.

- Perdido Street Station. London: Macmillan, 2000.

__ and Joan Gordon. 'Reveling in Genre: An Interview with China Miéville', Science Fiction Studies 30.3 (2003): pp.355-73.

Mills, Alice. 'Inspiration and Astonishment: Peake's Influence on Perdido Street Station', Peake Studies 7.4 (2002): pp.19-24.

Moorcock, Michael. 'Breaking Free; An Introduction to Mervyn Peake's Titus Alone', in Michael Moorcock and Allan Kausch (eds.), London 
Peculiar and Other Nonfiction. Oakland, CA: PM Press, 20I2. pp.257-9. Originally published in the Klett-Cotta German edition (20II) of Titus Alone.

- Death is no Obstacle. Manchester: Savoy, 1992. Angela Carter, 'Introduction' (199I), pp.ix-xii.

__ 'Facing the City; Review of Veniss Underground by Jeff VanderMeer' (2003), in Wizardry \& Wild Romance; A Study of Epic Fantasy. Revised edition. Austin: MonkeyBrain, 2004 [previous edition 1987]. pp.I83-5. Originally published in The Guardian under the title, 'Reinventing a vision' (29 Nov. 2003). <http://www.theguardian.com/books/2003/nov/ 29/featuresreviews.guardianreview2 $>$ [Accessed I9 Nov. 20I4].

'Preface' (1983), in Maeve Gilmore, A World Away; A Memoir of Mervyn Peake. London: Methuen, 1983 [1970]. pp.ix-xv.

Naipaul, V. S. The Enigma of Arrival; A Novel. London: Penguin, 1987.

Orwell, George. 'Charles Dickens' (1940), 'Wells, Hitler and the World State' (194I), in Peter Davison (ed.), The Complete Works of George Orwell. Vol. I2, A Patriot After All, 1940-4I. London: Secker \& Warburg, 1998. pp.20-57 and 536-4I, respectively.

- 'The True Pattern of H. G. Wells', Manchester Evening News (August 1946): p.2.

Peake, Mervyn. Gormenghast. London: Methuen, 1982 [1950].

'Introduction', in Drawings by Mervyn Peake. London: The Grey Walls Press, 1949. pp.7-II.

—_ Leon Garfield, and Edward Blishen (eds.). Sketches from Bleak House. London: Methuen, 1983.

__ 'London Fantasy', Peake Studies 9.4 (2006 [1949]): pp.3-7. First published in World Review 6 (August 1949): pp.55-9.

—-Mr Slaughterboard (c. 1933-6), in Maeve Gilmore (ed.) and John Watney (intr.), Peake's Progress; Selected Writings and Drawings of Mervyn Peake. London: Allen Lane, 1978. pp.63-94.

'The Artist's World', Peake Studies I2.2 (20II [1947]): pp.5-9. Previously published in The Mervyn Peake Review 8 (1979): pp.3-5.

— The Craft of the Lead Pencil. London: Allan Wingate, 1946. 
Peake, Mervyn, Titus Alone. London: Overlook Press, 1982 [pub. 1959; rev. 1970]. This edition follows the revised text of 1970, compiled by Langdon Jones for Eyre \& Spottiswoode with additional material from Mervyn Peake's drafts.

—— Titus Groan. London: Methuen, 1982 [1946].

Rogers, Philip. 'Dystopian Intertexts: Dickens's Hard Times and Zamiatin's We', Comparative Literature Studies 35.4 (1998): pp.393-4II.

Slater, Michael. Charles Dickens. New Haven and London: Yale University Press, 2009.

Smith, Gordon. Mervyn Peake; A Personal Memoir. London: Gollancz, 1984. Smith, Grahame. Dickens and the Dream of Cinema. Manchester: Manchester University Press, 2003.

Tolkien, J. R. R. 'On Fairy-Stories', in Christopher Tolkien (ed.), The Monsters and the Critics; and Other Essays. London: George Allen \& Unwin, 1983 [1947]. pp.I09-6I.

- - The Return of the King; Being the third part of The Lord of the Rings. London: HarperCollins, 2005 [1955].

Warncke, Wayne. 'George Orwell's Dickens', South Atlantic Quarterly 69 (1970): pp.373-8I.

White, Jerry. London in the Twentieth Century; A City and Its People. London: Penguin, 2002 [200I].

Winnington, G. Peter. The Voice of the Heart; the working of Mervyn Peake's imagination. Liverpool: Liverpool University Press, 2006.

—_ Vast Alchemies; The Life and Work of Mervyn Peake. London \& Chester Springs: Peter Owen, 2000.

Yeats, W. B. 'The Second Coming' (1920), in Richard J. Finneran (ed.), The Collected Poems of W. B. Yeats. Hampshire; New York: Palgrave, 1993 [1983]. p.I87.

Zamyatin, Yevgeny. 'On Language' (1919-20), and 'H. G. Wells' (1922), in Mirra Ginsburg (ed. and trans.), A Soviet Heretic: Essays by Yevgeny Zamyatin. Chicago \& London: University of Chicago Press, 1975 [1970]. pp.I75-89 and 259-90, respectively. 
Hadas Elber-Aviram is an Ors-funded doctoral candidate at University College London. Her dissertation charts the development of fantastical urban literature from Dickens's densely figurative representations of London, through the metropolitan science fiction of H. G. Wells and George Orwell, and the vertiginous, fragmented city of Peake's Titus Alone, to the array of steam-punk and science-fictional cityscapes of China Miéville's interstitial fiction. Hadas has been awarded Israeli and uK scholarships for work on the undergraduate and graduate levels, and has published on topics ranging from Dickens's influence on Miéville, through the representation of vampires in science-fiction, to the affiliations between urban archaeology and urban fantasy. 